\title{
HORVÁT NYELVTAN ALADÁRA EHRENHÖFERA I RÓKUSA VIDOVICSA - PRINOS HRVATSKOJ GRAMATIKOGRAFIJI 19. STOLJEĆA
}

dr. sc. Jadranka Mlikota, Filozofski fakultet, jmlikota@ffos.hr, Osijek; dr. sc. Ana Lehocki-Samardžić, Filozofski fakultet, alehocki@ffos.hr, Osijek

izvorni znanstveni članak

UDK 811.163.42’36(091)

rukopis primljen: 11. 9. 2017.; prihvaćen za tisak: 1. 12. 2017.

\begin{abstract}
U radu se donosi usporedba gramatike Aladára Ehrenhöfera i Rókusa Vidovicsa Horvát Nyelvtan (Budapest, 1897.) s gramatikama na koje se autori predgovorno pozivaju, a kojima su se služili u pisanju priručnika. S obzirom na to da su među gramatičkim uzorima navedene slovnice zagrebačke filološke škole i prijemaretićevske hrvatske (vukovske) gramatike, propituje se u kojim jezičnim obilježjima Horvát Nyelvtan slijedi hrvatsku jezičnu normu unutar Trojednice krajem 19. stoljeća.
\end{abstract}

Ključne riječi: Horvát Nyelvtan Aladára Ehrenhöfera i Rókusa Vidovicsa; gramatike hrvatskoga s mađarskim metajezikom; zagrebačka filološka škola

\section{Uvodno o mađarskoj sastavnici hrvatske gramatikografije 19. stoljeća}

Mađarska se sastavnica hrvatske gramatikografije može pratiti od druge polovice 19. stoljeća kada se bilježe prve jednojezične gramatike hrvatskoga pisane mađarskim metajezikom (Meršić i Vegh 2013: 344). Prva je do sada poznata takva gramatika, otisnuta izvan granica hrvatskoga (etničkoga i jezičnoga) prostora, Jánosa Mihálovicsa Gyakorlati Ilir Nyelvtan 
(Baja, 1874.), ${ }^{1}$ u prijevodu Praktična ilirska gramatika. ${ }^{2}$ Na nju je među prvima upozorio Ernest Barić (2001: 319-323) pridružujući ju nizu „ilirskih gramatika" (Barić 2006: 174) kojemu, uostalom, pripada i njezino drugo izdanje (1881.) (Mlikota, Baraban i Aleksa Varga 2106: 113-114). ${ }^{3}$ Istom nizu pripada i druga Mihálovicseva gramatika - Kratka slovnica za tri nižja razreda učionah pučnih (Baja, 1875.) ${ }^{4}$ - pa je zaključiti kako su obje „baštinile (...) hrvatska jezična obilježja kako su ih u svojim slovnicama baštinile i zagrebačke slovnice na hrvatskom etničkom prostoru druge polovice 19. stoljeća." (Mlikota i Lehocki-Samardžić 2016b). I premda su obje Mihálovicseve gramatike otisnute prije Horvát Nyelvtan (Nagy-Kanizsa, 1884.) ${ }^{5}$ Józsefa Margitayja, upravo je Margitayjeva jedina među gramatikama hrvatskoga na mađarskom jeziku 19. stoljeća uvrštena u Povijest hrvatskih gramatika (usp. Ham 2006: 123-124). ${ }^{6}$ Iz navedenoga se može zaključiti da je dosadašnji popis i opis

gramatika hrvatskoga na mađarskom jeziku druge polovice 19. stoljeća potvrdio dosadašnju oslonjenost mađarske sastavnice hrvatske jezikoslovne povijesti na svega dva gramatičara $i$ tri gramatička priručnika koji ni brojem do sada popisanih izdanja ne pokazuju ukupan ili bar približno točan prinos jednoga (mađarskoga) jezikoslovlja drugomu (hrvatskomu) ali i obrnuto (Lehocki-Samardžić i Mlikota 2016).

1 U okviru znanstveno-istraživačkoga projekta Hrvatsko-mađarski jezikoslovni dodiri u drugoj polovici 19. stoljeća (UNIOS IZIP-2014-26) objavljen je pretisak Mihálovicseve gramatike, a u izdanju Ogranka Matice hrvatske u Osijeku. Vidi: Mihálovics 1874.

2 O ostalim prijevodnim inačicama naslova gramatike vidi: Mlikota i Lehocki-Samardžić 2016a: 251.

3 O Mihálovicsevoj Praktičnoj ilirskoj gramatici vidi i: Mlikota i Lehocki-Samardžić 2016a: 251-303, Mlikota, Lehocki-Samardžić i Baraban 2016: 121-145.

4 Gramatika je otisnuta s tiskarskom pogrješkom u naslovu. Naime, na naslovnici piše učionah pučnih, a ne pučkih.

5 U prijevodu Hrvatska gramatika kako ju dalje i rabimo u radu.

6 Novija istraživanja (Lehocki-Samardžić i Mlikota 2016) potvrđuju da je Margitayjeva Hrvatska gramatika imala još dva izdanja - drugo je izdanje iz 1895., a opet je ponovljeno 1901. Tim se ponovljenim drugim izdanjem služimo u radu. 
Stoga upravo gramatika Aladára Ehrenhöfera i Rókusa Vidovicsa Horvát Nyelvtan (Budapest, 1897.), u prijevodu Hrvatska gramatika, ${ }^{7}$ tek odnedavna poznata u hrvatskoj jezikoslovnoj filologiji i mađarskoj slavistici (usp. Lehocki-Samardžić i Mlikota 2016), upotpunjuje još uvijek nedovoljno istraženu mađarsku sastavnicu hrvatske jezikoslovne (gramatikografske) povijesti druge polovice 19. stoljeća.

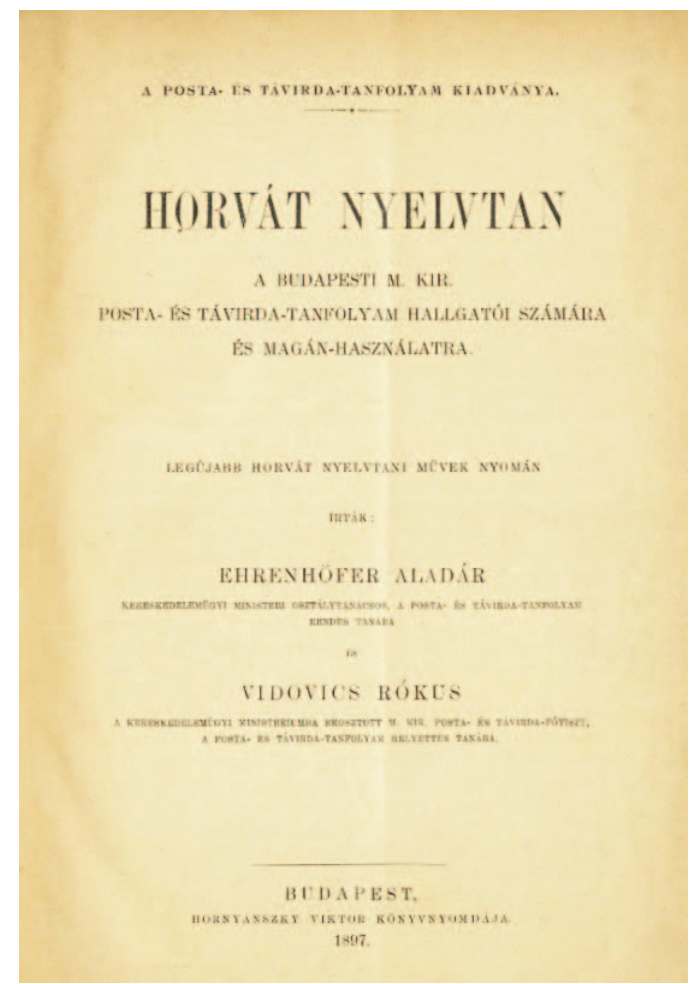

Slika 1. Naslovnica Horvát Nyelvtan

Valja istaknuti da su sve gramatike hrvatskoga na mađarskom jeziku, pa i Ehrenhöferova i Vidovicseva, izrazito pragmatične naravi: nastaju iz potrebe učenja hrvatskoga jezika nehrvatskih (ponajprije mađarskih)

\footnotetext{
7 U toj će se prijevodnoj inačici bilježiti naslov gramatike u ovom radu. Navodi iz Hrvatske gramatike prijevodno će se bilježiti u tekstu rada, a izvorni će se (mađarski) tekst izvornim slovopisom i pravopisom donositi u zagradi i(li) u podrubnoj napomeni.
} 
govornika. ${ }^{8}$ Riječ je o gramatičkim priručnicima u širem smislu riječi jer osim opisa jezičnih (gramatičkih) činjenica hrvatskoga jezika donose, između ostaloga, i vježbe za prevođenje i rječničke popise. ${ }^{9}$ Dosadašnji je (i jedini) opis Ehrenhöferova i Vidovicseva priručnika obuhvatio njegov ustroj, namjenu, normativni propis i opis, ali u odnosu na gramatičke priručnike hrvatskoga na mađarskom jeziku koji su mu prethodili Mihálovicsev (1874.) i Margitayjev (21895. [1901.]) (usp. LehockiSamardžić i Mlikota 2016). Izostala je pak usporedba Hrvatske gramatike s hrvatskom gramatičkom normom kakva je na hrvatskom (etničkom i jezičnom) prostoru krajem 19. stoljeća. Naime, Ehrenhöfer i Vidovics gramatiku objavljuju na samom kraju stoljeća kada se na hrvatskom nacionalnom prostoru počinju bilježiti vukovski upadi u normativni propis i opis pa je razložno propitati u kojoj mjeri priručnik (ne)slijedi hrvatsku jezičnu normu unutar Trojednice tim više što su autori već na naslovnici istaknuli da je gramatika „nastala na tragu najnovijih gramatičkih djela". ${ }^{10}$

8 S obzirom na to da su i Ehrenhöfer i Vidovics bili poštanski državni službenici (Ehrenhöfer je savjetnik ministra trgovine te redovni nastavnik tečaja pošte i brzojavnice, a Vidovics zaposlenik ministarstva trgovine, stariji časnik mađarske kraljevske pošte i brzojavnice i zamjenski nastavnik tečaja pošte i brzojavnice), a što je razvidno iz podataka danih na naslovnici gramatike, priručnik je ponajprije namijenjen „polaznicima tečaja mađarske kraljevske pošte i brzojavnice i za samostalnu uporabu” (s naslovnice, nepaginirano). U izvorniku: „A budapesti M. Kir. Posta és Távírda-tanfolyam hallgatói számára és magán-használatra.".

9 Ehrenhöferov se i Vidovicsev priručnik od ostalih gramatičkih priručnika hrvatskoga na mađarskom jeziku razlikuje ustrojem jer osim prijevodnih vježba i rječničkih popisa sadrži i Tekstove za čitanje (Olvasmányok) kojima je namjena višestruka: „početnicima služe kao vježba za čitanje, a naprednima za vježbu prijevoda, ali ujedno mogu služiti i kao ugodno štivo.” (Ehrenhöfer i Vidovics 1897: IV). U izvorniku: „...kezdőknek olvasási gyakorlatul, a haladottabbaknak pedig fordításul és kellemes olvasmány gyanánt szolgálhatnak.". Tako strukturirane gramatike razlikuju se od gramatika otisnutih na tlu Trojednice na kraju 19. stoljeća jer „priručnici koji su uključivali rječničke, dijaloške i književne sadržaje, ali i opis osnova pravopisa, do kraja stoljeća svojevrsnim prijelazom isključivo u opis gramatičkih sastavnica jezika u potpunosti su izgubile navedene strukturne dijelove" (Brlobaš 2015: 462).

10 U izvorniku: „Legújabb horvát nyelvtani művek nyomán”. 


\section{Metodologija i ciljevi}

S obzirom na to da podatak na naslovnici Ehrenhöferova i Vidovicseva gramatičkoga priručnika tek daje naslutiti uzore na čijim temeljima počiva normativni propis i opis, o njima se više podataka pronalazi u predgovoru Hrvatske gramatike; autori ondje ističu da su se

Za vrijeme pisanja ove knjige služili (...) sljedećim hrvatskim gramatičkim djelima: Antun Mažuranić: Slovnica Hrvatska. Adolfo Veber: Slovnica hrvatska. Josip Vitanović: Gramatika hrvatskoga jezika. Mirko Divković: Oblici. (Ehrenhöfer i Vidovics 1897: IV). ${ }^{11}$

Iz popisanih se uzora može razabrati da normativni propis i opis $\mathrm{u}$ Hrvatskoj gramatici počiva na temeljima zagrebačke filološke škole ugrađene u Mažuranićev i Veberov gramatički propis premda se među popisanima nalazi i Vitanovićev gramatički priručnik, u kojem se već bilježi „ponešto ustupaka sve proširenoj vukovskoj normi" (Ham 2006: 118), i Divkovićev u kojem se i znatnije prepoznaju obilježja prijemaretićevskih hrvatskih vukovskih gramatika. ${ }^{12}$ Ono što autori uz popisane uzore ipak nisu naveli, to je kojim su se izdanjem gramatika služili. Naime, Mažuranićeva je Slovnica hèrvatska za gimnazije i realne škole ${ }^{13}$ imala četiri izdanja (Zagreb, 1859., ${ }^{2} 1861 .,{ }^{3} 1866 .,{ }^{4} 1869$.) koja su „prema autorovim riječima u predgovorima izdanja (...) objavljena s pojedinim promjenama, popravcima i dodatcima” (Brlobaš 2008: 170), no to „su uglavnom neznatne promjene u odnosu na sam sadržaj gramatičkoga opisa" (isto). Kako Ehrenhöfer i Vidovics naslov Mažuranićeve slovnice svojevoljno bilježe bez popratnoga mukloga è uz slogotvorni /r/ (hrvatska, a ne hèrvatska), ne može se sa sigurnošću tvrditi ni da su se služili posljednjim, trećim, izdanjem Veberove

11 U izvorniku: „Könyvünk megírásánál a következő horvát nyelvtani műveket használtuk: Antun Mažuranić: Slovnica Hrvatska. Adolfo Veber: Slovnica hrvatska. Josip Vitanović: Gramatika hrvatskoga jezika. Mirko Divković: Oblici.".

12 Ham (2006: 132) pod tim nazivom podrazumijeva hrvatske gramatike koje su „zadržavale (...) iz hrvatske tradicije toliko da budu prepoznatljivo hrvatske, a iz vukovštine primale toliko da budu pretežito vukovske.". Riječ je o gramatikama nastalima u posljednjim desetljećima 19. stoljeća, objavljenima prije Gramatike i stilistike hrvatskoga ili srpskoga književnog jezika (1899.) Tomislava Maretića. O gramatikama Mirka Divkovića vidi i: Smajić 2006.

13 Dalje u radu naslov kratimo u Slovnica hèrvatska. 
Slovnice hrvatske za srednja učilišta (Zagreb, $\left.{ }^{3} 1876.\right)^{14}$ u kojem je, između ostaloga, uvedena takva slovna promjena. Vitanovićeva je pak Gramatika hrvatskoga jezika za školu i samouke ${ }^{15}$ u kratkom vremenu imala čak četiri izdanja (Osijek, 1880., $\left.{ }^{2} 1882 .,{ }^{3} 1888 .,{ }^{4} 1891.\right)$ - kojim su se izdanjem služili autori Hrvatske gramatike, također nije navedeno, no valja istaknuti kako se jezični sustav u svim četirima izdanjima Gramatike hrvatskoga jezika ,još uvijek (...) u svojim bitnim obilježjima prepoznaje kao sustav zagrebačke filološke škole" (Mlikota 2016: 361) s obzirom na to da su ustupci hrvatskoj vukovskoj normi, i to mahom tek u četvrtom izdanju, većim dijelom samo nazivoslovni (Mlikota 2016: 359-360). Nije navedeno ni izdanje Divkovićevih Oblika hrvatskoga jezika za srednje škole ${ }^{16}$ (Zagreb, $\left.{ }^{2} 1887 .,{ }^{3} 1890 .,{ }^{4} 1894 .,{ }^{5} 1895.\right),{ }^{17}$ premda su sva četiri izdanja, kronološki gledano, od svih gramatika uzora najbliža vremenu objavljivanja Hrvatske gramatike. Stoga je i pretpostaviti da se normativni pomaci i u Ehrenhöferovu i Vidovicsevu priručniku bar donekle bilježe onako kako se bilježe u gramatičkim priručnicima u posljednjem desetljeću 19. stoljeća na tlu Trojednice. Ipak, od nekih se vukovskih normativnih pomaka autori dijelom i sami predgovorno ograđuju:

Smatramo potrebnim na kraju naglasiti da smo novosti iz najnovijih gramatika, poput: - da se umjesto dosad primjenjivanog analitičkog načina pisanja, koji je ujedno bliži i mađarskom pravopisu, u njima primjenjuje fonetski pravopis, tj. upotrebljavaju pravopis koji je potpuno u skladu s izgovorom, iz čega proizlazi da dvojinu uopće ne koriste, a i u II. padežu množine nema ' $h$ '; u III., VI., i VII. padežu množine u prvoj i trećoj deklinaciji isti je nastavak 'ima', a kod druge deklinacije tvore se nastavkom 'ama', - potpuno zanemarili kod pisanja ovog djela jer s jedne strane ove novine nisu općeprihvaćene u široj javnosti, a s druge pak kompliciraju gramatiku i otežavaju učenje onima kojima hrvatski nije materinski jezik (Ehrenhöfer i Vidovics 1897: IV). ${ }^{18}$

\footnotetext{
14 Dalje u radu naslov kratimo u Slovnica hrvatska.

15 Dalje u radu naslov kratimo u Gramatika hrvatskoga jezika.

16 Dalje u radu naslov kratimo u Oblici.

17 Prvo je izdanje Oblika objavljeno u Zagrebu 1879. godine, a naslovljeno je Hrvatske gramatike I. dio. Oblici (Ham 2006: 136-137, Brlobaš 2015: 434) pa je, zapravo, riječ o ukupno pet izdanja iste gramatike s dvjema inačicama naslova.

18 U izvorniku: „Szükségesnek tartjuk végül megjegyezni, hogy a legújabb nyelvtanokban felmerülő újításokat, a milyenek: - hogy az eddigi szokásos és a magyar helyesíráshoz is
} 


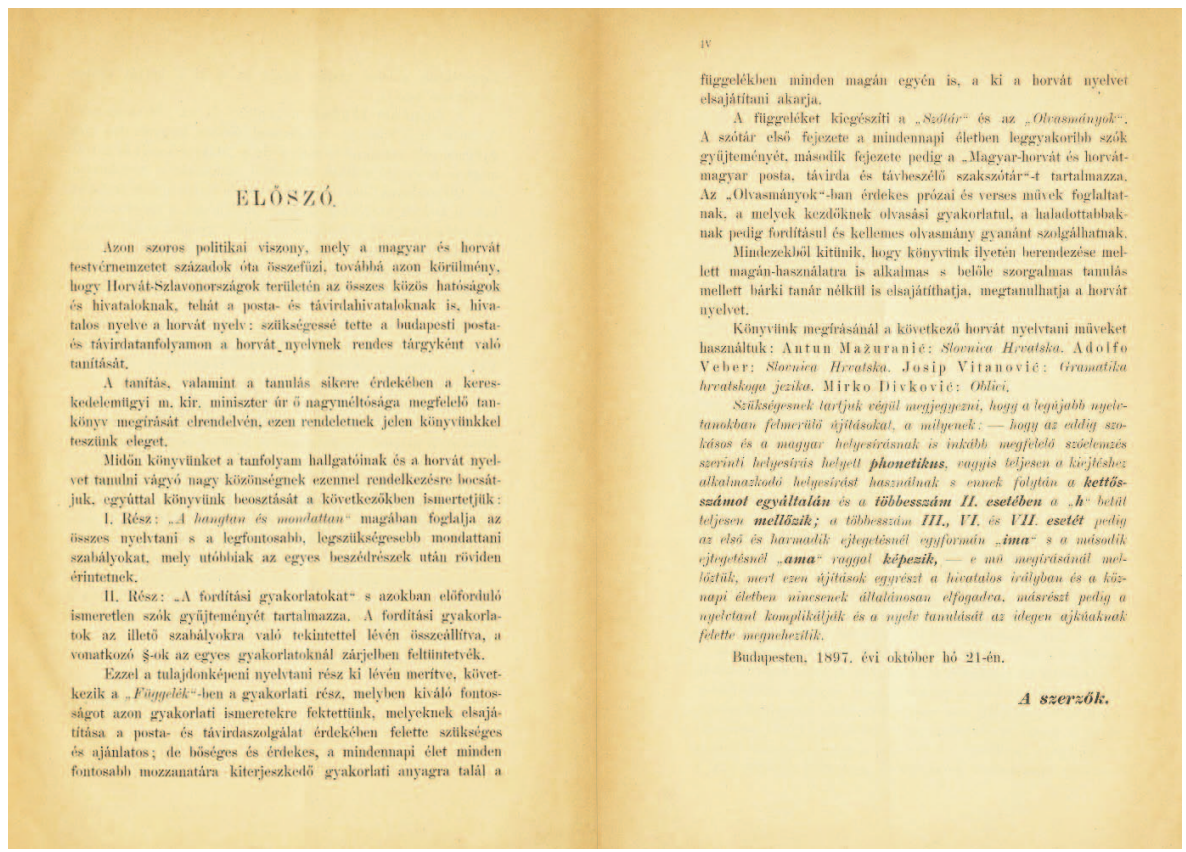

Slika 2. Predgovor gramatike Horvát Nyelvtan

Iz svega se navedenoga može pretpostaviti da je uz zagrebačka obilježja, bez obzira na navedene pravopisne i morfološke ograde, Ehrenhöferova i Vidovicseva Hrvatska gramatika mogla polučiti i još neka obilježja prijemaretićevskih hrvatskih (vukovskih) gramatika. ${ }^{19}$ Koja i kolika bit će razvidno usporedbom normativnoga propisa i opisa u Hrvatskoj gramatici s posljednjim izdanjem gramatičkih priručnika koji su navedeni kao normativni uzori.

inkább megfelelő szóelemzés szerinti helyesírás helyett phonetikus, vagyis teljesen a kiejtéshez alkalmazkodó helyesírást használnak s ennek folytán a kettősszámot egyáltalán és a többesszám II. esetében a 'h' betűt teljesen mellőzik; a többesszám III., VI. és VII. esetét pedig az első és harmadik ejtegetésnél egyformán 'ima' s a második ejtegetésnél 'ama' raggal képezik, - e mủ megírásánál mellőztük, mert ezen újítások egyrészt a hivatalos irályban és a köznapi életben nincsenek általánosan elfogadva, másrészt pedig a nyelvtant komplikálják és a nyelv tanulását az idegen ajkúaknak felette megnehezítik.”.

19 Naime, ta su obilježja osobito razvidna u posljednjem dijelu gramatičkoga priručnika Tekstovi za čitanje (Olvasmányok) (Ehrenhöfer i Vidovics 1897: 275-298). Autori „nisu naveli izvore iz kojih preuzimaju ulomke pa jezičnim obilježjima tekstovi, pokatkad, ne slijede normativne preporuke u gramatičkom dijelu priručnika" (Lehocki-Samardžić i Mlikota 2016). 
Usporedba s posljednjim izdanjem gramatika uzora temelji se na dvama razlozima: prvi je što su posljednja izdanja tek neznatno izmijenjena u odnosu na prethodna, a drugi što su vremenom objavljivanja najbliža objavljivanju Hrvatske gramatike pa se time opravdava i napomena autorā da je gramatika nastala na tragu najnovijih gramatičkih dijela. Ako se izdvojenim jezičnim obilježjem posljednje izdanje ipak razlikuje od prethodnih, u analizi će se posebno upozoriti. Upozorit će se na ona obilježja kojima se normativni propis u Hrvatskoj gramatici razlikuje u odnosu na propis u gramatikama uzorima, bilo da su te razlike razvidne u pojedinačnim rješenjima gramatičara iste filološke škole (zagrebačke) ili je riječ o obilježjima kojima se filološke škole (zagrebačka i vukovska) razlikuju, a pripadaju jezičnim razinama koje su zajedničke svim gramatikama. Izdvojena će obilježja biti dana prema poretku opisa u Hrvatskoj gramatici s obzirom na to da autori u tome ne slijede ni jednu od gramatika na koje se predgovorno pozivaju. ${ }^{20}$ Usporedbi će jezičnih obilježja prethoditi usporedba ustroja gramatičkoga dijela Ehrenhöferova i Vidovicseva priručnika s gramatikama uzorima.

\section{Usporedba Hrvatske gramatike s gramatikama uzorima na tlu Trojednice}

\subsection{Ustroj gramatičkoga dijela priručnika}

Gramatički dio Ehrenhöferova i Vidovicseva priručnika obaseže gotovo trećinu knjige. Gramatičke činjenice hrvatskoga jezičnoga sustava razložene su u fonološka (dijelom i fonetska) i morfološka poglavlja, odnosno unutar poglavlja većega broja paragrafa. U dvama se kratkim paragrafima navode i pravopisne pojedinosti - 6. § donosi obrazloženje pravopisnih načela (etimološkoga i fonološkoga) uz napomenu o pisanju slova ć, a 7. §obuhvaća tri temeljna pravila o pisanju velikoga početnoga slova. Samo je jedan paragraf, 25., sintaktičkoga sadržaja: Niječne i upitne rečenice (Tagadó és kérdő mondatok) (Ehrenhöfer i Vidovics 1897: 25-26) pojašnjene su na kraju opisa imeničnoga sustava, a prije opisa pridjeva. $\mathrm{Uz}$

\footnotetext{
20 Valja istaknuti da poredak opisa promjenjivih vrsta riječi (imenice, pridjevi, brojevi, zamjenice, glagoli) u Hrvatskoj gramatici posve odgovara poretku u gramatikama hrvatskoga na mađarskom jeziku koji su joj prethodili, Mihálovicsevoj Praktičnoj ilirskoj gramatici (usp. Mlikota i Lehocki-Samardžić 2016a: 268) i Margitayjevoj Hrvatskoj gramatici ( ${ }^{2} 1895$ [1901]: 50-91) pa se može pretpostaviti da je Ehrenhöferu i Vidovicsu bio poznat i rad gramatičara izvan Trojednice.
} 
opis je imenica dana i prezentska paradigma jesnoga i niječnoga oblika glagola biti, ${ }^{21}$ a uz brojeve i primjeri sprezanja glagola u perfektu. ${ }^{22}$ Donošenje pojedinosti glagolskoga sustava unutar opisa sklonidbenih vrsta izrazito je pragmatične naravi, što potvrđuju i drugi gramatički priručnici hrvatskoga na mađarskom jeziku, primjerice Mihálovicseva Praktična ilirska gramatika (usp. Mlikota, Lehocki-Samardžić i Baraban 2016: 135). Ustrojem je Hrvatska gramatika u odnosu na gramatike uzore najbliža Divkovićevim Oblicima kojima je pripadna fonologija i fonetika hrvatskoga jezika (u domeni raspodjele glasova i naglasnoga sustava) te morfologija promjenjivih vrsta riječi, premda Hrvatska gramatika, a za razliku od Oblika, donosi i morfologiju nepromjenjivih vrsta riječi. U Hrvatskoj gramatici dakle izostaje tvorbeni opis koji sadrže i Mažuranićeva (1869: 108-133) i Veberova (1876: 82-92) slovnica, ${ }^{23}$ a nema ni sintaktičkoga uvrštenoga u Veberov (1876: 93-206) i Vitanovićev (1891: 83-124, 134-180) normativni priručnik. Ono što je svim uspoređivanim gramatikama zajedničko u strukturi osnovne su pravopisne napomene koje će, uostalom, i biti dijelom gramatičkih priručnika na tlu Trojednice sve do kraja 19. stoljeća (Brlobaš 2015: 462).

\subsection{Slovopisna, fonološka, fonetska i pravopisna rješenja}

Uvodnim (Bevezetés) poglavljem Ehrenhöferove i Vidovicseve (1897: 3-6) Hrvatske gramatike obuhvaćene su fonološke i fonetske činjenice hrvatskoga jezičnoga sustava svedene na popis i opis glasova, glasovnih promjena i napomena o hrvatskom naglasnom sustavu, a dvama paragrafima i kratke pravopisne pojedinosti - Pravilno pisanje riječi (A szók helyesírása) i Veliko početno slovo (Nagy kezdöbetük).

Autori u Hrvatskoj gramatici pojmovno ne razlikuju slovo od glasa pa navode da „U hrvatskom pismu ima 30 slova” (Ehrenhöfer i Vidovics 1897: $3)^{24}$ čiji se „izgovor (...) većinom podudara s mađarskim izgovorom” (isto). ${ }^{25}$

\footnotetext{
21 Usp. 24. §: „'Biti’ = lenni, konjugacija pomoćnog glagola u izjavnom načinu sadašnjeg vremena. Izjavni način. - Sadašnje vrijeme. (Potvrdni oblik.) (Negacijski oblik.) (Ehrenhöfer i Vidovics 1897: 25). U izvorniku: „Biti’ = lenni, segédige ragozása a jelentő mód jelen időben. Jelentő mód. - Jelen idő. (Állító alak.) (Tagadó alak.)”.

22 Usp. 44. §: „Svršena sadašnjost (prošlost) glagolskih oblika” (Ehrenhöfer i Vidovics 1897: 39-41). U izvorniku: „Az igék végzett jelen (múlt) ideje.”.

23 Veber je tvorbeni opis strukturirao u odnosu na Mažuranićev (Brlobaš 2015: 448).

24 U izvorniku: „A horvát írásban 30 betű van.”.

25 U izvorniku: „... kiejtése többnyire a magyar használattal megegyez.”.
} 
Takva nazivoslovna interferencija u hrvatskoj gramatičkoj literaturi postoji do druge polovice 19. stoljeća kada se u gramatikama pojmovi glas i slovo pretežno razlikuju (Brlobaš i Horvat 2006: 50-51), no u gramatičkim priručnicima hrvatskoga na mađarskom jeziku i dalje ostaju neizdiferencirani (usp. Mlikota i Lehocki-Samardžić 2016: 273).

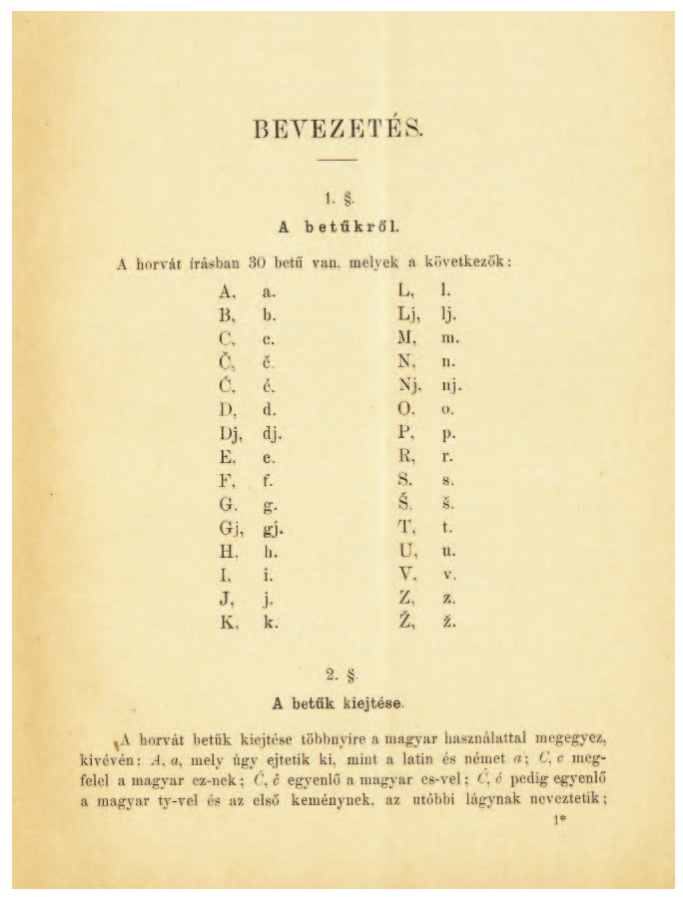

Slika 3. Početni paragrafi Uvoda

U paragrafu Podjela slova (A hangok felosztása) dana je osnovna podjela glasova na samoglasnike (magánhangzók) i suglasnike (mássalhangzók) (Ehrenhöfer i Vidovics 1897: 4). Popisom samoglasnika nije obuhvaćen dvoglasnik ie čiji opis daju Mažuranić (1871: 4), ${ }^{26}$ Veber (1876: 6) i Vitanović (1891: 2), a tek je iz primjera razvidno da ga u gramatici autori u tom slovnom rješenju bilježe na mjestu dugoga jata, dok na mjestu kratkoga bilježe je. ${ }^{27}$ Divković (1895: 5) će među Samoglasnicima staroga slavenskoga jezika također opisati

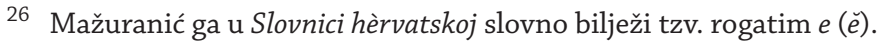

27 Usp. rieč, zvier, nesviest, pripoviest, čovjek, mjesec, sjeme (Ehrenhöfer i Vidovics 1897: 10-11).
} 
jat, ali će ga slovno bilježiti ije/je prihvaćajući za dugi odraz jata vukovsko rješenje, a ne ostajući pri zagrebačkom koje je u Oblicima bilježio do četvrtoga, pretposljednjega, izdanja (1894.) (Smajić 2006: 207). U suglasničkom sustavu za fonem /d/ u skladu sa slovničarima zagrebačke filološke škole, Mažuranićem (1869: 30) i Veberom (1876: 21), ali i Vitanovićem (1891: 3), autori bilježe dva slovna znaka, dj i gj, te ga izgovorno uspoređuju s mađarskim glasom bilježenim gy (Ehrenhöfer i Vidovics 1897: 4). Ne navode distribucijsku razliku navedenih dvoslova u domaćih, odnosno tuđih riječi ${ }^{28}$ kakva je dana u gramatikama na koje se predgovorno pozivaju. ${ }^{29}$ Suglasnički je sustav pojednostavljen s obzirom na to da za fonem /ć/ nemaju dva slovna znaka ć i tj, baš kao ni Vitanović (1891: 2) ni Divković (1895: 3), već samo ć (Ehrenhöfer i Vidovics 1897: 4). Ni slogotvorni / $r$ / ne bilježe dvoslovom er, ${ }^{30}$ kao što ga, uostalom, na tlu Trojednice ne bilježe gramatički priručnici od Veberova (1876: 5- 6) trećega izdanja Slovnice hrvatske. ${ }^{31}$

Istim, uvodnim, poglavljem obuhvaćena je i artikulacijsko-akustična razdioba glasova kojom je dana podjela suglasnika „prema govornim organima"32 (Ehrenhöfer i Vidovics 1897: 4) što odgovara podjeli u gramatikama uzorima. ${ }^{33}$ Toj je podjeli, pa uzoru na Mažuranića (1869: 5), dodana i podjela suglasnika na

„1. meke: c, č, ć, š, ž, j (ponekad i r);

2. tvrde: ostali." (Ehrenhöfer - Vidovics 1897: 4) suglasnike. ${ }^{34}$

28 Da je ipak uporaba dvoslova dj i gj u skladu sa zagrebačkom normom, dijelom se može razabrati iz naslova rječničkih poglavlja priručnika (usp. Magjarsko-hrvatski dio (Magyarhorvát rész.) (Ehrenhöfer i Vidovics 1897: 247), Hrvatsko-magjarski dio (Horvát-magyar rész.) (Ehrenhöfer i Vidovics 1897: 261)) kao i iz hrvatskih rečeničnih primjera vježba za prevođenje. Usp. „Jedna trećina stanovnika su Magjari (...)” (Ehrenhöfer i Vidovics 1897: 101), „(...) ona pako upisuje medjunarodne zamotke.” (Ehrenhöfer i Vidovics 1897: 105).

29 Divković (1895: 14) u Oblicima fonem / đ/ bilježi jednoslovom đ te navodi da je takvo bilježenje tek odnedavno „uvedeno u hrvatsko pisanje” (isto) pa se „još i danas rado piše gj, Gj" (isto). Stoga takvo bilježenje dopušta u imenima (Gjurgjevac, Gjuro, Gjurgjević) dok se ne ustali novo slovno rješenje uvedeno Brozovim Hrvatskim pravopisom (1893).

30 Usp. smrt, četvrt, brv, krv, drvo, vrt (Ehrenhöfer i Vidovics 1897: 10-11).

31 Zanimljivo je pripomenuti da dvije godine prije Vebera to slovno rješenje ima Mihálovics u Praktičnoj ilirskoj gramatici (Baja, 1874.), otisnutoj izvan granica hrvatskoga (etničkoga i jezičnoga) prostora. Vidi: Mlikota, Baraban i Aleksa Varga 2016: 118-119.

32 U izvorniku: „beszélő szerveink szerint”.

33 Usp. Mažuranić 1869: 4-5, Veber 1876: 7, Vitanović 1891: 2, Divković 1895: 11.

34 U izvorniku: „1. lágyak: c, č, ć, š, ž, j (némelykor az $\mathbf{r}$ is); 2. kemények: a többiek.”. 
Naglasne su napomene u Hrvatskoj gramatici svedene samo na mjesto naglaska u jednosložnih, dvosložnih, trosložnih i višesložnih riječi ${ }^{35}$ pa izostaje mogućnost usporedbe s naglasnim sustavom u gramatikama na koje se autori predgovorno pozivaju. Takve su uzgredne napomene i pravopisne kao što je, uostalom, već i navedeno, a uzgredan je i pregled Glasovnih promjena (Hangváltozás) (Ehrenhöfer i Vidovics 1897: 4-5) s obzirom na to da su mahom oprimjerene padežnim oblicima imenica i pridjeva.

Iz opisa je uvodnoga poglavlja Hrvatske gramatike razvidno da autori na opisanim razinama slijede zagrebačke uzore - Vebera s obzirom na slovna rješenja za dugi odraz jata (ie) i slogotvorni $/ r /(r)$, a Mažuranića $s$ obzirom na razdiobu glasova. Tek se izostavljanjem dvoslova tj za fonem $/ \grave{c} /$ u ovom dijelu gramatičkoga priručnika prepoznaje i hrvatska vukovska sastavnica (usp. Ham 2006: 127).

\subsection{Morfologija promjenjivih vrsta riječi}

Autori su se već predgovorno, kao što je istaknuto, u sklonidbi promjenjivih vrsta riječi ogradili od "novosti iz najnovijih gramatika” koje se tiču izostavljanja dvojine, nebilježenja završnoga $h$ u G mn. imenične sklonidbe te novoštokavskoga množinskoga padežnoga sustava jer takve „novine nisu općeprihvaćene u široj javnosti” što dijelom normativnim propisom doista potvrđuju i Vitanović i Divković. Vitanović, primjerice, u Gramatici hrvatskoga jezika novoštokavske sinkretizirane množinske nastavke u DLI donosi tek u zagradi iz čega je razvidno da je staroštokavskim nastavcima dana prednost (Mlikota 2016: 357), a Divković, koji u sklonidbenim paradigmama navodi samo novoštokavske nastavke, u bilješkama ipak domeće:

Taj se padež [dativ - istaknule autorice] izjednačio s instr. množine, te ima nastavak -ima. Pored toga govore se i oblici za dat. s nastavkom -im, n. pr. stvarim, za lokat. s nastavkom -ih, n. pr. stvarih, a za instr. s nastavkom -mi, n. pr. stvarmi. Pretežniji su oblici s nastavkom -ima. (Divković 1895: 36). ${ }^{36}$

\footnotetext{
35 Usp. „Prilikom čitanja naglasak je redovito: na jednosložnim riječima na tom jednom, kod dvosložnih riječi na drugom slogu, kod trosložnih i višesložnih riječi pada na treći slog." (Ehrenhöfer i Vidovics 1897: 5). U izvorniku: „Az olvasásnál a hangsúly rendszerint: az egyszótagú szavaknál erre, a kétszótagú szavaknál a második szótagra, három és több szótagú szavaknál a harmadik szótagra esik.”.

36 Usp. i ostale Bilješke k padežima uz sklonidbene riječi u Oblicima.
} 
Ostala pak navedena pojedinačna rješenja od kojih se Ehrenhöfer i Vidovics ograđuju već su dijelom gramatičkoga propisa i Vitanovićeva i Divkovićeva te su izrazitije obilježje hrvatske vukovske norme s kraja stoljeća. Tim će, hrvatskim vukovskim, obilježjima biti pripadna i podjela imeničnih sklonidaba u pet vrsta prema nastavku u N jd. koju Ehrenhöfer i Vidovics ipak ne preuzimaju od Vitanovića (1891: 14) i Divkovića (1895: 18-19). ${ }^{37}$

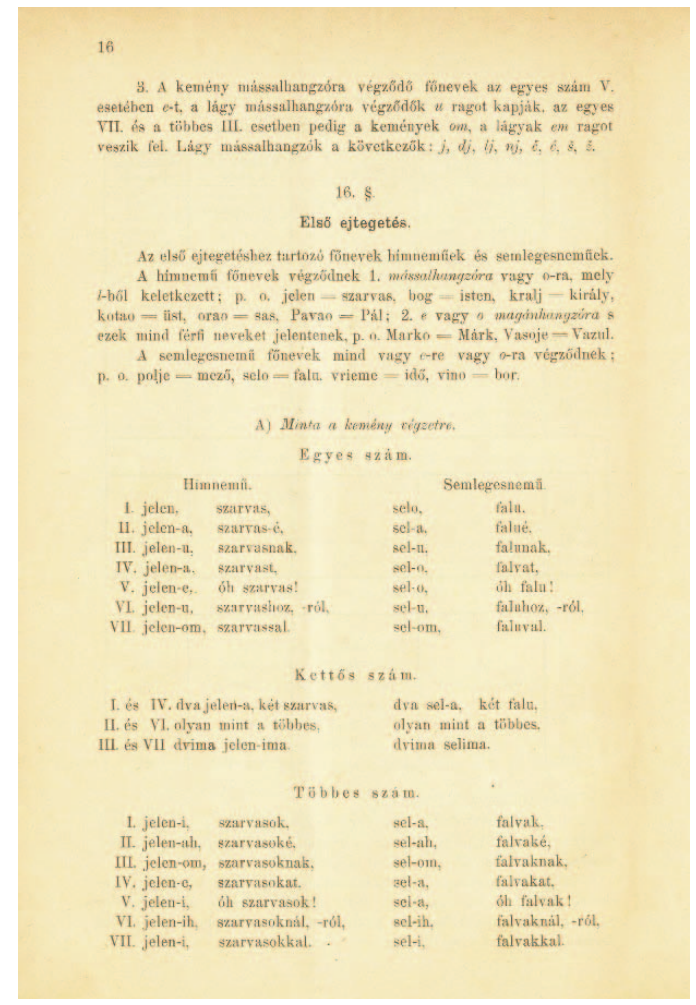

Slika 4. Sklonidbeni sustav (I. deklinacija)

37 Usp. danu podjelu imenica u Hrvatskoj gramatici prema nastavku u G jd.: „Imenice se u hrvatskom jeziku dekliniraju na tri načina prema čemu razlikujemo tri deklinacije. Kojoj deklinaciji pripada koja imenica, može se odrediti prema obliku genitiva jednine koji kod I. deklinacije završava na - $a$, kod II. ne -e, kod treće na -i." (Ehrenhöfer i Vidovics 1897: 14). U izvorniku: „A horvát főnevek háromféleképp ejtegettetnek, mihezképest három ejtegetést is különböztetünk meg. Melyik ejtegetéshez tartozik valamely főnév, azt az egyes szám sajátító esetéből tudhatjuk meg, mely az I. ejtegetésnél a-ra, a II-iknál e-re, a III-iknál i-re végződik.". 
S druge pak strane Mažuranićevi (1869: 52) nastavci -ieh i -iem (uz nastavke -ih i -im) u sklonidbi određenih pridjeva više nisu dijelom Veberova (1876: 48) normativnoga propisa, ${ }^{38}$ također ni Ehrenhöferova i Vidovicseva (1897: 27), premda ih u Gramatici hrvatskoga jezika u sklonidbenoj paradigmi (u zagradama) opet ima Vitanović, ${ }^{39}$ a i Divković (1895: 46) u Oblicima oblike „žutijem, žutijeh, vrućijem, ljućijeh” također smatra dopustivima. U odnosu pak na Mažuranića (1869: 53) koji i u stupnjevanju pridjeva ima dvostruke oblike (jačji/jači, dražji/draži, brz/bržji itd.), u ostalim se gramatikama uzorima takvi dvostruki oblici više ne pronalaze, ${ }^{40}$ a nema ih ni Hrvatska gramatika (usp. Ehrenhöfer i Vidovics 1897: 29-32).

Veberov će se normativni propis u odnosu na Mažuranićev dijelom razlikovati i u sklonidbi glavnih brojeva s obzirom na to da, za razliku od Mažuranića (1869: 58-59), više ne propisuje sklonidbu brojeva od pet pa nadalje, ${ }^{41}$ a tako je i u Vitanovića (1891: 42), Divkovića (1895: 52), ali i Ehrenhöfera i Vidovicsa (1897: 34-36).

U zamjeničnom se sustavu, između ostaloga, Hrvatska gramatika kao sljednica zagrebačkih gramatičkih uzora prepoznaje i normiranjem zanaglasnoga A jd. zamjenice ona u obliku ju (Ehrenhöfer i Vidovics 1897: 42) dok gramatičari prijeloma norme, Vitanović (1891: 33) i Divković (1895: 45), za isti zanaglasni akuzativ imaju dvostruke oblike ju/je. ${ }^{42} \mathrm{I}$ u ostalim će se (sklonidbenim) pojedinostima zamjeničnoga sustava Vitanovićeva i Divkovićeva gramatika prepoznati kao gramatika prijemaretićevskih hrvatskih (vukovskih) obilježja, a Ehrenhöferova i Vidovicseva i ovdje ostaje zagrebačkih obilježja kakva su u Veberovoj Slovnici hrvatskoj. Tako se, primjerice, i u Veberovu (1876: 45) i Ehrenhöferovu i Vidovicsevu (1897: 47) normativ-

\footnotetext{
38 Veber (1871: 47) ih ne navodi ni u prvom izdanju svoje slovnice.

39 Usp.: „Oblik 'žutieh' u 2. pad. množine pridjeva s tvrdim dočetnim suglasnikom, zatim 'žutiem' u 7. pad. jednine i 3., 6. i 7. pad. množine ostanci su stare zamjenične sklonitbe pridjeva.” (Vitanović 1891: 37).

40 Usp. Veber 1876: 50-52, Vitanović 1891: 38-40, Divković 1895: 49-52.

41 Usp. Veberovu (1876: 53) napomenu: „(..) No buduć da se takovim dekliniranjem glavni brojnici pomrsuju u rečenih padežih s rednimi, to se za razliku u novijem jeziku, osobito štokavskom, glavni brojnici, počam od p e t, drže svuda za nesklonive samostavnike (...)".

42 Zanaglasni A jd. zamjenice ona Vitanović u prvim trima izdanjima Gramatike bilježi u skladu sa zagrebačkom normom, a tek u četvrtom izdanju normira dvostruke zanaglasne oblike. No u metajeziku i u tom izdanju uvijek rabi oblik ju (Mlikota 2016: 358).
} 
nom propisu više ne pronalaze Mažuranićeve (1869: 67) dvostrukosti u zamjenica (tko/gdo, što/ča), a nemaju ih ni Vitanović (1891: 32) ni Divković (1895: 40).

U glagolskom je sustavu Hrvatska gramatika također naslonjena na Veberov (1876: 56-77) normativni propis u kojem više nema Mažuranićeva (1869: 91) futura za neizvjesnost: ako/kada uzkupujem. Hrvatska gramatika u glagolskom sustavu čuva obilježja zagrebačke filološke škole koja se u nekim prijemaretićevskim hrvatskim (vukovskim) gramatikama već prestaju bilježiti. Primjerice, u glagolskom je sustavu i buduće prošlo vrieme (futurum exactum): bit ću kupovao (Ehrenhöfer i Vidovics 1897: 52, 67) koje bilježe slovnice zagrebačke filološke škole, ${ }^{43}$ zadržava ga još uvijek i Vitanović (1891: 76) u Gramatici hrvatskoga jezika, ali ne više i Divković (1895: 85) u Oblicima.

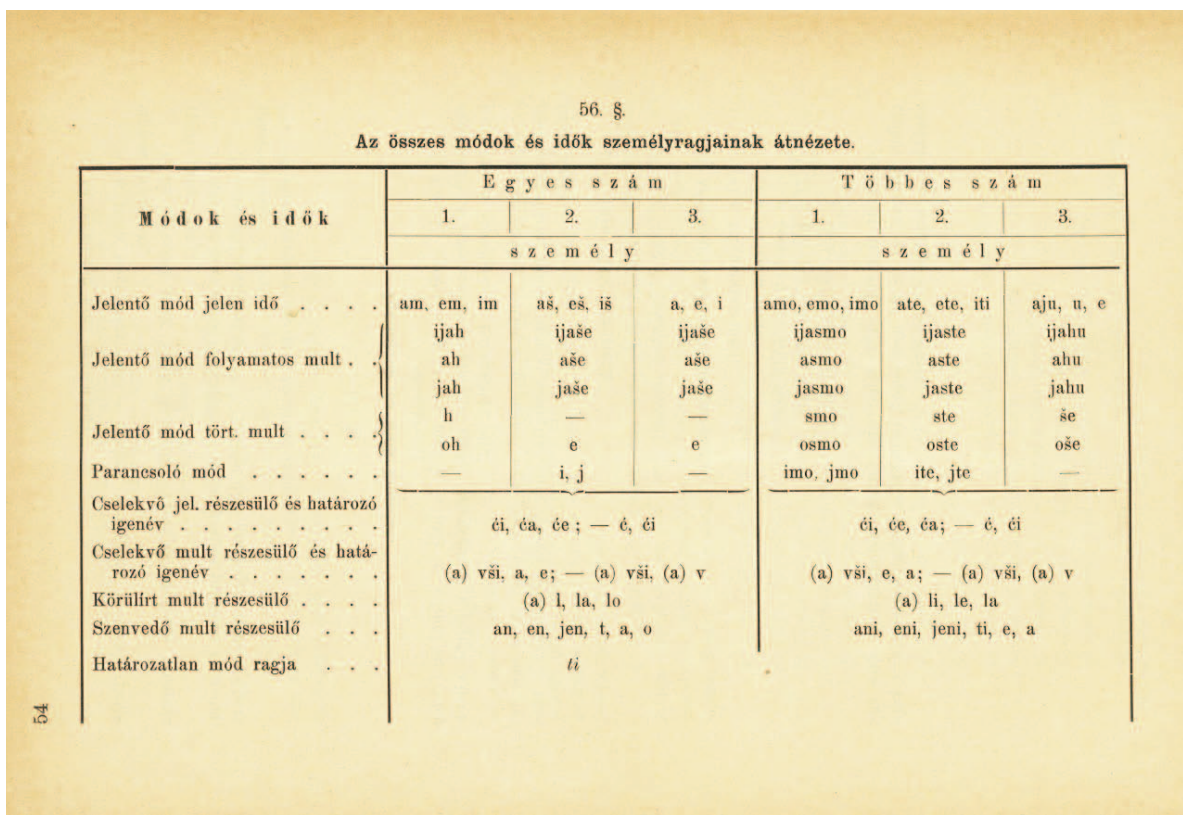

Slika 5. Pregled glagolskih vremena i načina

43 Usp. Mažuranić 1869: 91, Veber 1876: 72-73. 
I u morfologiji se promjenjivih vrsta riječi, zaključiti je, Ehrenhöferov i Vidovicsev gramatički priručnik naslanja na normativni propis zagrebačke filološke škole prepoznatljiv u Veberovim normativnim rješenjima iz Slovnice hrvatske, a ta rješenja većim dijelom još uvijek nastavlja i Vitanović četvrtim izdanjem Gramatike hrvatskoga jezika. Divkovićevi će Oblici (i) petim izdanjem potvrditi znatnije ustupke hrvatskoj vukovskoj normi.

\section{Zaključak}

Vrijeme objavljivanja Ehrenhöferove i Vidovicseve Hrvatske gramatike vrijeme je smjena filoloških škola na tlu Trojednice. U tom se međurazdoblju, kako ga određuje Branka Tafra (1995: 167), „s jedne strane napušta ilirski tip književnoga jezika, a s druge strane jača 'češći' tip književne novoštokavštine i fonološko pravopisno načelo.” (isto). Ipak, gramatike hrvatskoga na mađarskom jeziku otisnute krajem 19. stoljeća izvan granica hrvatskoga (etničkoga i jezičnoga) prostora, kojima pripada i Ehrenhöferova i Vidovicseva Hrvatska gramatika, ne bilježe navedene promjene što pokazuje da su

izvanjezični razlozi znatno manje utjecali na normativne priručnike izvan hrvatskih granica jer unutar njih upravo sociopolitičke prilike hrvatski jezik već tada počinju usmjeravati drugim i bitno drugačijim normizacijskim putovima. (Mlikota, Baraban i Aleksa Varga 2016: 126)

Na takav zaključak upućuje i usporedba jezičnih obilježja Hrvatske gramatike s normativnim uzorima na koje se autori predgovorno pozivaju. Normativnim propisom Hrvatska je gramatika najbliža Veberovoj Slovnici hrvatskoj koji tek osuvremenjuje pokoja Mažuranićeva rješenja. Podatak na naslovnici da je gramatika „nastala na tragu najnovijih gramatičkih djela” odnosio se, pretpostaviti je, upravo na posljednja dva navedena gramatička uzora, na Vitanovića i Divkovića, jer su vremenski njihova gramatička djela najbliža objavljivanju Hrvatske gramatike. Riječ je o prijemaretićevskim hrvatskim (vukovskim) gramatikama od kojih Ehrenhöfer i Vidovics preuzimaju (i time nastavljaju) ona jezična obilježja koja su i dalje prepoznatljivo zagrebačka. Tako je u Hrvatskoj gramatici znatno više istih normativnih rješenja danih (i) u Vitanovićevoj Gramatici hrvatskoga jezika negoli u Divkovićevim Oblicima s obzirom na to da su ustupci hrvatskoj vukovskoj normi u Divkovića ipak izrazitiji. Divkovićevim je Oblicima 
Ehrenhöferov i Vidovicsev gramatički dio priručnika najbliži sadržajem s obzirom na to da mu je pripadna fonologija i fonetika te morfologija (i) promjenjivih vrsta riječi, a ne sadrži poglavlja sintaktičkoga i tvorbenoga sadržaja.

Osim Mažuranića, Vebera, Vitanovića i Divkovića u Hrvatskoj gramatici drugi gramatički uzori nisu navedeni. No kako je ustroj pojedinih (morfoloških) poglavlja sličan ustroju u gramatikama hrvatskoga na mađarskom jeziku, Mihálovicsevoj (1874., ${ }^{2} 1881$.) i Margitayjevoj ( ${ }^{2} 1895$. [1901.]), čije je objavljivanje prethodilo Hrvatskoj gramatici, pretpostaviti je da su autorima mogli bili poznati i normativni priručnici izvan Trojednice. Svi oni otisnuti izvan hrvatskoga (etničkoga i jezičnoga) prostora normativnim propisom na kraju 19. stoljeća nastavljaju naravni tijek razvoja hrvatskoga standardnoga jezika i upotpunjuju mađarsku sastavnicu njegove jezikoslovne povijesti.

\section{Literatura}

Barić, Ernest (2001) „Narječja u književnojezičnoj koncepciji Józsefa Margitaija (na temelju njegove Hrvatske gramatike, Horvát Nyelvtan, iz 1884.)", u: Drugi hrvatski slavistički kongres, ur. Dubravka Sesar, Ivana Vidović Bolt, sv. 1., Hrvatsko filološko društvo, Filozofski fakultet, Zagreb, Osijek, 319-323.

Barić, Ernest (2006) Rode, a jezik?!: radovi jezikoslovne kroatistike, Znanstveni zavod Hrvata u Mađarskoj, Pečuh.

Brlobaš, Željka (2008) „Slovnica Hèrvatska Antuna Mažuranića”, u: Antun Mažuranić: Slovnica Hèrvatska za gimnazije i realne škole. Dio I. Rěčoslovje [pretisak: Institut za hrvatski jezik i jezikoslovlje, Zagreb, 2008.], 165-206.

Brlobaš, Željka (2015) „Hrvatske gramatike u 19. stoljeću”, u: Povijest hrvatskoga jezika, 4. knjiga: 19. stoljeće, ur. Josip Lisac, Ivo Pranjković, Marko Samardžija, Croatica, Zagreb, 433-461.

Brlobaš, Željka, Marijana Horvat (2006) „Fonološko nazivlje u hrvatskim gramatikama 19. stoljeća", Filologija, 46-47, 49-66.

Ham, Sanda (2006) Povijest hrvatskih gramatika, Nakladni zavod Globus, Zagreb.

Lehocki-Samardžić, Ana, Jadranka Mlikota (2016) „Horvát Nyelvtan Aladára Ehrenhöfera i Rókusa Vidovicsa", izlaganje na Međunarodnom 
kroatističkom znanstvenom skupu, Pečuh, 21. i 22. listopada 2016., rad u tisku.

Margitay, József (21895. [1901.]) Horvát Nyelvtan, Kiadja Fischel Fülöp könyvkereskedése, Nagy-Kanizsa.

Meršić, Žuža, Ivona Vegh (2013) „Mađarska gramatika međimurskoga jezika", Studia Slavica Saveriensia, 1-2, 344-353.

Mihálovics, János (1874) Gyakorlati Ilir Nyelvtan, Szigriszt Gyula Bizománya, Baja [pretisak: Ogranak Matice hrvatske u Osijeku, Osijek, 2016.].

Mlikota, Jadranka (2016) „Vitanovićevi jezikoslovni prinosi”, u: Šesti hrvatski slavistički kongres. Zbornik radova sa znanstvenoga skupa s međunarodnim sudjelovanjem održanoga u Vukovaru i Vinkovcima od 10. do 13. rujna 2014., prvi svezak, ur. Stipe Botica, Davor Nikolić, Josipa Tomašić, Ivana Vidović Bolt, Hrvatsko filološko društvo, Zagreb, 353-363.

Mlikota, Jadranka, Borko Baraban, Melita Aleksa Varga (2016) „Gyakorlati Ilir Nyelvtan Jánosa Mihálovicsa”, u: Od početaka do danas. 120 godina budimpeštanske kroatistike, ur. István Lukács, Institut za slavensku i baltičku filologiju Filozofskog fakulteta Sveučilišta Loránda Eötvösa, Budimpešta, 111-127.

Mlikota, Jadranka, Ana Lehocki-Samardžić (2016a) „Gyakorlati Ilir Nyelvtan Ivana Mihalovića - prinos mađarskoj sastavnici hrvatske jezikoslovne povijesti”, u: János Mihálovics: Gyakorlati Ilir Nyelvtan, Szigriszt Gyula Bizománya, Baja, 1874. [pretisak: Ogranak Matice hrvatske u Osijeku, Osijek, 2016.], 251-303.

Mlikota, Jadranka, Ana Lehocki-Samardžić (2016b) „Gramatički priručnici Ivana Mihalovića”, izlaganje na znanstvenom skupu Od norme do uporabe, Filozofski fakultet Osijek, 16. i 17. rujna 2016., rad u tisku.

Mlikota, Jadranka, Ana Lehocki-Samardžić, Borko Baraban (2016) „Tragom Mažuranićeve Slovnice Hèrvatske u gramatičkom priručniku Jánosa Mihálovicsa Gyakorlati Ilir Nyelvtan”, Rasprave. Časopis Instituta za hrvatski jezik i jezikoslovlje, 42, 1, 121-145.

Smajić, Dubravka (2006) Gramatike Mirka Divkovića, doktorska disertacija, Sveučilište Josipa Jurja Strossmayera u Osijeku, Filozofski fakultet Osijek.

Veber, Adolfo (1871) Slovnica hèrvatska za srednja učilišta, Troškom spisateljevim, Zagreb.

Tafra, Branka (1995) Jezikoslovna razdvojba, Matica hrvatska, Zagreb. 


\section{Vrela}

Divković, Mirko (1895) Oblici hrvatskoga jezika za srednje škole, izdanje peto, Tisak dioničke tiskare, Zagreb.

Ehrenhöfer, Aladár, Rókus Vidovics (1897) Horvát Nyelvtan, Hornyánszky Viktor Könyvnyomdája, Budapest.

Mažuranić, Antun (1869) Slovnica hèrvatska za gimnazije i realne škole. Dio I. Rěčoslovje, četvèrto izdanje, Troškom knjižare Fr. Župana (Albrechta i Fiedlera), Zagreb.

Veber, Adolfo (1876) Slovnica hrvatska za srednja učilišta, Troškom spisateljevim, Zagreb.

Vitanović, Josip (1891) Gramatika hrvatskoga jezika za školu i samouke, IV. popunjeno izdanje, Troškom spisateljevim, a u komisiji knjižare Lav. Hartmana (Kugli i Deutsch), Zagreb. 


\section{SUMMARY}

Jadranka Mlikota and Ana Lehocki-Samardžić ALADAR EHRENHÖFER AND ROKUS VIDOVICS' HORVAT NYELVTAN - A CONTRIBUTION TO CROATIAN $19^{\text {th }}$ CENTURY

\section{LINGUISTICS}

This paper is a comparison of Aladar Ehrenhöfer and Rokus Vidovics' grammar book called Horvat Nyelvtan (Budapest, 1897) with the grammar books mentioned by the authors in the preface which they used as references while writing their grammar book. Since we find the grammar books by the Zagreb Philological School among the linguistic references, the aim of this paper is to try to answer the question of which linguistic features in Horvat Nyelvtan follow the Croatian linguistic standard within Trojednica at the end of the $19^{\text {th }}$ century.

Keywords: Aladar Ehrenhöfer and Rokus Vidovics' Croatian Grammar; Croatian grammar books with Hungarian metalanguage; Zagreb Philological School

\section{ÖSSZEFOGLALÓ \\ Jadranka Mlikota és Ana Lehocki-Samardžić EHRENHÖFER ALADÁR ÉS VIDOVICS RÓKUS: HORVÁT NYELVTAN - ADALÉK A 19. SZÁZADI HORVÁT GRAMMATIKOGRÁFIÁHOZ}

A dolgozatban Ehrenhöfer Aladár és Vidovics Rókus Horvát Nyelvtan (Budapest 1897.) címủ művének összevetése történik azokkal a nyelvtanokkal, melyekre a szerzőpáros a bevezetőben hivatkozik, és melyeket munkája folyamán használt. Tekintettel arra, hogy a nevezett források között fellelhetőek a zágrábi filológiai iskola, illetve a Maretićet megelőző időszakra jellemző Vuk Karadžić-féle horvát grammatikák is, külön figyelmet érdemel annak feltáró vizsgálata, hogy a Horvát Nyelvtanban milyen módon nyilvánul meg a 19. század végi Szerb-Horvát-Szlovén Királyságra jellemző horvát nyelvi norma követése.

Kulcsszavak: Ehrenhöfer Aladár és Vidovics Rókus: Horvát Nyelvtan; Horvát Nyelvtan magyar metanyelv által; zágrábi filológiai iskola 